\title{
PENERAPAN SISTEM MANAJEMEN MUTU ISO 9001:2008 DALAM PELAYANAN PUBLIK DI PT. PLN RAYON MATTOANGIN
}

\author{
Ridzuan Bin Rusman ${ }^{1}$, Abdul Mahsyar ${ }^{2}$, Abdi $^{3}$ \\ 1) Jurusan Ilmu Administrasi Negara Unismuh Makasssar \\ 2) Jurusan Ilmu Administrasi Negara Unismuh Makassar \\ 3) Jurusan Ilmu Administrasi Negara Unismuh Makassar
}

\begin{abstract}
This study aimed to describe the quality of management system ISO 9001: 2008 in the public service of PT PLN (Persero) Mattoangin district. Type of this research was quantitative descriptive with 30 employees as respondents. Technique of data analysis used is descriptive statistics. The results shown that the application of the principles of ISO 9001: 2008, for PT PLN (Persero) public serviced in South Makassar area at Rayon Mattoangin in general be categorized very high.the indicator that included in the category of very higt, among others, the indicators that observed in the variablewas an indicator focus on the customer, indicators of employee involvement, process approach, approach to the management system, continual repair, factual approach to take decision, mutual relationships with suppliers. The only one category that included in high category, that is a leadership.
\end{abstract}

Keywords: quality management system, public service

\begin{abstract}
ABSTRAK
Penelitian ini bertujuan untuk mengetahui gambaran penerapan sistem manajemen mutu ISO 9001:2008 dalam pelayanan publik PT PLN (Persero) Rayon Mattoangin. Jenis penelitian ini adalah deskriptif kuantitatif dengan responden sebanyak 30 orang karyawan.Teknik analisis data yang digunakan adalah statistik deskriptif. Hasil penelitian menunjukkan bahwa penerapan prinsip-prinsip SMM ISO 9001:2008. Dalam Pelayana Publik PT PLN (Persero) Area Makassar Selatan Rayon Mattoangin secara umum di kategorikan sangat tinggi. Indikator yang dikategorikan sangat tinggi antara lain indikator fokus pada pelanggan, indikator keterlibatan karyawan, pendekatan proses, pendekatan pada sistem manajemen, perbaikan terus menerus, pendekatan faktual pada pengambilan keputusan, hubungan yang saling menguntungkan dengan pemasok. Hanya satu kategori tinggi, yaitu kepemimpinan.
\end{abstract}

Kata kunci: sistem manajemen mutu, pelayana publik 


\section{PENDAHULUAN}

Era globalisasi, menuntut Badan Usaha Milik Negara (BUMN) untuk meningkatkan pelayanan secara profesional sesuai dengan bidangnya masing-masing.Badan Usaha Milik Negara (BUMN) yang ada di Indonesia berpengaruh dalam perkembangan dunia usaha dan masyarakat.Oleh karena itu, dalam mengatur dan menjalankan usahanya, BUMN diatur dan dikelola oleh pemerintah.

PT. PLN (Persero) merupakan salah satu Perusahaan Milik Negara yang memberikan pelayanan kepada pelanggan dan masyarakat dalam penyediaan jasa penjualan tenaga listrik di Indonesia.Peningkatan kebutuhan listrik melonjak dengan tinggi dan cepat, sehubungan dengan itu diiringi pula dengan standar tingkat kepuasan masyarakat menjadi lebih tinggi lagi.Berdasarkan UUD RI No. 30 Tahun 2009 tentang ketenaga listrikan.

Usaha penyediaan tenaga listrik dikuasai oleh negara dan penyediaannya perlu terus ditingkatkan sejalan dengan perkembangan pembangunan agar tersedia tenaga listrik dalam jumlah yang cukup, merata dan bermutu.

Upaya yang di lakukan ialah Penerapan. Sistem manajemen mutu suatu standar yang lebih berorientasi kepada sistem dan proses, Salah satu standar sistem manajemen mutu (SMM) yang paling populer adalah ISO 9001: 2008.

Organisasi pengelola standard internasional ini adalah International Oraganization fot Standardization yang bermarkas di Jeneva-Swiss, didirikan pada 23 February 1947, kini beranggotakan lebih dari 147 negara yang mana setiap Negara diwakili oleh badan standardisasi nasional (Indonesia diwakili oleh KAN-Komite Akreditasi Nasional).

Masalah pelayan adalah hal yang biasa terjadi tidak terlepas juga di PT. PLN (Persero) Rayon Mattoangin, yang pelayannya masih kurang memuaskan, namun sudah Bersertifikasi ISO, permasalah yang masih sering terjadi seperti pembayaran rekening listrik yang terkadang jaringan nya tiba-tiba off line, pelayanan pemasangan listrik baru yang terbilang mahal, perubahan daya setelah beberapa hari terjadi 
koslet, pelayanan keluhan pelanggan yang tidak responsip, pemadaman lampu yang sebelunya tidak ada pemberitahuan dan terkadang berlangsung lama, dan permasalahan lain sebagainya.

Istilah pelayanan berasal dari kata "laya" yang artinya menolong atau menyediakan segala apa yang diperlukan oleh orang lain untuk perbuatan melayani. Pada dasarnya setiap manusia membutuhkan pelayanan, bahkan secara ekstrim dapat dikatakan bahwa pelayanan tidak dapat dipisahkan dengan kehidupan manusia

Sinambela(2007:3).

Pelayanan pada dasarnya dapat didefinisikan sebagai aktivitas seseorang, kelompok/organisasi baik langsung maupun tidak langsung untuk memenuhi kebutuhan menurut Harbani Pasolong (2007:4).

Menurut Kasmir (2003:216), mendefinisikan bahwa pelayanan adalah setiap kegiatan yang diperuntukan dan ditujukan untuk memberikan kepuasan kepada nasabah, melalui pelayanan yang dapat memenuhi keinginan dan kebutuhan nasabah.
Menurut Gronroos dalam Ratminto (2005:2) mendefinisikan bahwa pelayanan adalah serangkaian aktivitas yang bersifat tidak kasat mata yang terjadi akibat adanya interaksi antara konsumen dengan karyawan atau hak-hak lain yang disediakan oleh perusahaan pemberi pelayanan yang dimaksudkan untuk memecahkan permasalahan konsumen/pelanggan.

Menurut J.S Badudu dalam Sutan Muhammad Zain (2001:781), mendefinisikan pelayanan sebagai hal, cara, atau hasil pekerjaan melayani. Sedangkan melayani adalah menyuguhi (orang) dengan makanan dan minuman, menyediakan keperluan orang.Kualitas yang dalam hal ini adalah kepuasan pelanggan sepenuhnya

(fullcostumer satisfaction), dimana suatu produk berkualitas apabila dapat memberikan kepuasan sepenuhnya kepada konsumen yaitu sesuai dengan apa yang diharapkan atas suatu produk, kualitas sebagai standar yang harus dicapai oleh seorang, sekelompok, lembaga maupun organisasi mengenai kualitas sumber daya manusia, kualitas cara 
kerja, proses dan hasil kerja atau produk berupa barang dan jasa (Trigono, 1997 : 76).

Monier (2002:12) pelayanan umum adalah "Setiap kegiatan yang dilakukan oleh pihak lain yang ditujukan guna memenuhi kepentingan orang banyak.

Berdasarkan uraian diatas, pelayanan yang dilakukan oleh sebuah organisasi akan membawa keuntungan bagi organisasi itu sendiri terutama untuk eksistensi dan reputasi organisasi, sehingga untuk mewujudkan hal itu adalah sangat bergantung kepada bagaimana kualitas pelayanan yang dihadirkan oleh sebuah organisasi kepada pengguna pelayanan itu sendiri.

Menurut Vincent Gaspersz (2001: 5), Kualitas terdiri dari sejumlah keistimewaan produk, baik keistimewaan langsung maupun keistimewaan atraktif yang memenuhi keinginan pelanggan dan dengan demikian memberikan kepuasan atas penggunaan produk itu. Kualitas terdiri dari segala sesuatu yang bebas dari kekurangan atau kerusakan.
Menurut Fandy Tjiptono dan Anastasia Diana (2003:3), Kualitas terdiri dari kualitas dari segi design dan kesesuaian dimana diantara keduanya terdapat beberapa kesamaan elemen-elemen yang terdiri dari: kualitas meliputi usaha memenuhi atau melebihi harapan pelanggan. Kualitas mencakup produk dan jasa, manusia, proses, dan lingkungan. Kualitas merupakan kondisi yang selalu berubah (misalnya apa yang dianggap merupakan kualitas saat ini mungkin dianggap kurang berkualitas pada masa yang akan datang.

Beberapa pendapat para ahli tentang dimensi kualitas pelayanan, dapat disimpulkan beberapa dimensi yang kredibel yaitu dengan memenuhi syarat agar sebuah pelayanan memungkinkan untuk menimbulkan kepuasan pelanggan. Adapun dimensi-dimensi tersebut yaitu: Tangibles atau bukti fisik, Reliability atau keandalan Responsiveness atau ketanggapan, Assurance atau jaminan/ kepastian, Empathyatau kepedulian.

Rivai (2005:62) mengatakan definisi Total Quality Management 
(TQM) adalah konsep yang memerlukan komitmen dan keterlibatan pihak manajemen dan seluruh pengelola perusahaan untuk memenuhi keinginan atau kepuasan pelanggan secara konsisten.

Beberapa konsep yang telah diuraikan di atas maka nampak jelas bahwa sebenarnya Total Quality Management merupakan sebuah proses manajemen yang harus dikendalikan dan membutuhkan partisipasi seluruh unsur yang ada dalam sebuah organisasi maupun perusahaan.

Dengan mengimplementasikan TQM tersebut, diharapkan mampu meningkatkan kualitas manajemen dan mampu meningkatkan daya saing perusahaan.

Hal itu harus dilakukan oleh para perusahaan guna menghadapi persaingan diera global seperti saat sekarang ini.Seiring dengan adanya globalisasi saat ini maka standarisasi manajemen telah menjadi isu utama, diman yang lebih khusus adalah standarisasi sistem manajemen Kualitas.Untuk itu suatu perusahaan harus mempersiapkan kerangka sistem manajemen kualitas bagi perusahaan, guna menuju kearah yang diinginkan sesuai dengan sasaran atau tujuan akhir yang ditetapkan oleh manajemen perusahaan yang bersangkutan.Hal itu dalam pengertian bahwa tujuan atau sasaran kualitas perusahaan dapat tercapai sesuai dengan keinginan yang diharapakan oleh para pelanggan atau investor perusahaan yang bersangkutan.Salah satu standar manajemen Kualitas bagi negara maju dan bahkan negaranegara berkembang adalah ISO 9001:2000.

ISO berasal dari kata Yunani ISOS yang berarti sama, kata ISO bukan diambil dari singkatan nama sebuah organisasi walau banyak orang awam mengira ISO berasal dari International Standard of Organization. ISO 9001 merupakan standar Internasional yang mengatur tentang system manajement mutu (Quality Management System), Oleh karena itu seringkali disebut sebagai "ISO 9001, QMS" adapun tulisan 2008 menunjukkan tahun revisi, maka ISO 9001:2008 adalah system manajemen mutu ISO 9001: hasil revisi tahun 2008. 
Menurut ISO, Sistem kerja karyawannya atau job Manajemen Mutu ISO 9001:2008 dibangun atas (delapan) Prinsip. involvement.

Pendekatan Proses,Sebuah Kedelapan Prinsip yang merupakan ruh dari standar ISO 9001:2008 ini dituangkan dalam bentuk klausulklausul (persyaratan) sistem manajemen mutu ISO 9001:2008 yang juga berjumlah 8 (delapan) klausul. Kedelapan Prinsip itu adalah:

Fokus Pada Pelanggan, Keberlangsungan suatu perusahaan sangatlah bergantung kepada pelanggannya. Perusahaan yang menerapkan sistem manajemen mutu ISO 9001:2008 diharuskan memiliki strategi khusus untuk terus menerus memantau kepuasan pelanggan.

Kepemimpinan, Pemimpin merupakan elemen terpenting didalam suatu organisasi. Keberhasilan suatu organisasi biasanya dimulai dari kecakapan pemimpin dalam memaksimalkan potensi sumber daya yang dimilikinya.

Keterlibatan karyawan, Sumber daya manusia sangat penting peranannya dalam suatu perusahaan maka kita perlu tahu keterlibatan 
menguntungkan dan meningkatkan kemampuan keduanya untuk mencapai target.

\section{METODE PENELITIAN}

Penelitian ini akan dilaksanakan kurang lebih selama dua bulan.Penelitian ini berlokasi di PT PLN (Persero) Area Makaassar Selatan Rayon Mattoangin.disertai dengan pertimbangan bahwa saya melakukan penelitian mengenai SMM ISO (9001:2008) adalah untuk mengetahui bagaimana Gambaran Penerapan SMM ISO (9001:2008).

Jenis penelitian ini adalah penelitian Deskriptif kuantitatif, tipe penelitian ini adalah penelitian survey. Populasi pada penelitian ini adalah seluruh karyawan PT PLN (Persero) Area Makasar Selatan Rayon Mattoangin. Sampel dalam penelitian ini sebanyak 30 orang. Dalam penelitian ini, pengumpulan data dilakukan melalui beberapa teknik yakni observasi, dokumentasi dankusioner. Pengembangan instrumen menggunakan uji validitas dan uji reliabilitas.

Teknik analisis data setelah data penelitian ini terkumpul, maka data dianalisis dengan mengunakan analisis statistik deskriptif yang disesuaikan dengan rumusan masalah, dengan langka-langka sebagai berikut: 1,Sebelum dilakukan analisis data terlebih dahulu dilakukan a. pengecekan data, b. penyekoran jawaban, c. merapikan data dan mengatur data hasil penyekoran, dan d.melakukan pengecekan data dengan mencocokkan data yang telah di acak dengan data yang tertera pada konsep tabulasi. 2,Rumus presentasi skor untuk setiap indikator adalah :Indikator $=$ Jumlah skor responden/Jumlah skor ideal X 100 $=$ jumlah skor perolehanTiap indikator. 
Tabel 2.Scoring nilai responden.

\begin{tabular}{|c|c|l|}
\hline No & scroing & \multicolumn{1}{|c|}{ Keterangan } \\
\hline 1 & $0-20$ & Sangat Rendah \\
\hline 2 & $21-40$ & Rendah \\
\hline 3 & $41-60$ & Sedang \\
\hline 4 & $61-80$ & Tinggi \\
\hline 5 & $81-100$ & Sangat Tinggi \\
\hline
\end{tabular}

Sumber Data Primer diolah (2016)

\section{HASIL DAN PEMBAHASAN}

Pada penelitian ini menggunakan beberaa indikator untuk mengetahui penerapan sistem manajemen ISO 9001:2008 dalam pelayanan publik PT PLN (Persero) Area Makassar Selatan Rayon Mattoangin diantaranya 1, Fokus pada pelangan 2, Kepemimpinan 3, Keterlibatan karyawan 4, Pendekatan proses 5, Pendekatan pada sistem manajemen 6, Perbaikan terus menerus 7, Pendekatan faktual pada pengambilan keputusan 8, Hubungan yang saling menguntungkan dengan pemasok.

Berdasarkan hasil penelitian data dan informasi yang telah dikumpulkan oleh peneliti, maka langkah selanjutnya yang dilakukan peneliti adalah melakukan analisis terhadap data yang dikumpulkan, sehingga data yang diperoleh dapat menjawab permasalahanpermasalahan yang telah dirumuskan.Dalam melakukan analisis ini peneliti menggunakan teknik analisis statistik. Proses analisis dilakukan dengan mendeskripsikan data-data yang telah terkumpul, dalam bentuk tabulasi dan distribusi frekuensi. Kemudian disusun secara sistematis sehingga memper mudah peneliti dalam menarik suatu kesimpulan.

Untuk mengetahui seberapa tinggi penerapan Sistem Manajemen Mutu ISO 9001:2008 di PT PLN (Persero) Area Makassar Selatan Rayon Mattoangin adalah Fokus 
Pada Pelangan, dapat disimpulkan dalam indikator fokus pada pelanggan mendapatkan perolehan nilai sebesar 84,76, dapat di katakan tinggi terlihat dari hasil analisis sejumlah data pertanyaan yang dilakukan di PT PLN (Persero) Area Makassar Selatan Rayon Mattoangin. Berdasarkan hasil tersebut pelayanan terhadap konsumen yang dilakukan oleh PT. PLN (Persero) Area Makassar Selatan Rayon Mattoangin, telah memenuhi kriteria antara lain.

$$
\text { Indikator fokus pada }
$$

Konsume seperti halnya PT. PLN Area Makassar Barat Rayon Mattoangin. Terus menerus memperbaiki teknolagi, proses danjasa/ produknya serta selalu mengidentifikasi kebutuhan konsumennya hal hal tersebut merupakan point penting yang sangat di perhatikan oleh PT. PLN (Persero) Area Makassar Selatan Rayon Mattoangin, sehingga dapat diakatakn bahwa Indikator fokus pada konsumen di PT. PLN (Persero) Area Makassar Selatan Rayon Mattoangin, sangat tinggi dan bisa diakatakan masuk dalam kriteria dari salah satu indiktor prinsip ISO 9001:2008 pelayana Publik yang telah diterapkan oleh PT. PLN (Persero) Area Makassar Selatan Rayon Mattoangin.

Kepemimpinan, dapat disimpukan dalam indikator kepemimpinan mendapatkan perolehan nilai sebesar 80,6 dapat di katakan sangat tinggi terlihat dari hasil analisis sejumlah data pertanyaan yang dilakukan di PT PLN (Persero) Area Makassar Selatan Rayon Mattoangin.

Hasil dari perhitungan di atas menunjukkan bahwa penilaian terhadap indikator kedua prinsip kedua ISO 900:2008, yaitu kepemimpinan masuk dalam kategori tinggi hal ini membuktikan bahwa kepemimpina yang diterpkan oleh pipinan PT. PLN (Persero) Area Makassar Selatan Rayon Mattoangin, sudah baik karna pimpinan sudah menetapkan dan mengutamakan hala hal sebagai berikut, pimpina menetapkan target sesuai dengan tujuan perusahaan, pimpinan memberikan teguran dan sangsi kepada karyawan yang melakukan pelangaran-pelangaran saat bekerja 
serta pimpinan memberikan motovasi kepada karyawan melalui promosi jabatn. Upaya-upaya yang dilakukan oleh diatas cukup mengambarkan bagaimana sistem kepemimpinan yang diterapkan PT. PLN (Persero) Area Makassar Selatan Rayon Mattoangin, telah memenuhi kriteria ISO dan efektif untuk meningkatkan kualitas kinerja karyawan PT. PLN (Persero) Area Makassar Selatan Rayon Mattoangin. Keterlibatan Karyawan, Dapat disimpukan dalam indikator Keterlibatan Karyawan mendapatkan perolehan nilai sebesar 83,58 dapat di katakan sangat tinggi terlihat dari hasil analisis sejumlah data pertanyaan yang dilakukan di PT PLN (Persero) Area Makassar Selatan Rayon Mattoangin.

Keterlibatan karyawan merupakan salah satu hal utama dalam keberhasilan suatu perusahaan berdasarkan hasil perhitungaan diatas menunjukkan bahwa keterlibatan karyawan pada PT. PLN (Persero) Area Makassar Selatan Rayon Mattoangin, sangat tinggi dengan adanya beberapa upaya yang dilakukan seperti selalu berpartisipasi aktif bekerja baik tugas individu atau kelompok berupaya selalu menyelesaikan pekerjaan dengan maksimal serta tidak segan lembur untuk menyelesaiakn tugastugas yang sedang dikerjakan. Beberapa upaya tersebut yang telah di lakukan karyawan PT. PLN (Persero) Area Makassar Selatan Rayon Mattoangin, sehinga dapat dikatankan penerapan prinsip ISO9001:2008 pada PT. PLN (Persero) Area Makassar Selatan Rayon Mattoangin, sangat baik dan masuk dalam indikator sangat tinggi.

Pendekatan Proses, Dapat disimpukan dalam indikator Pendekatan Proses pada pelanggan mendapatkan perolehan nilai sebesar 83,11 dapat di katakan sangat tinggi terlihat dari hasil analisis sejumlah data pertanyaan yang dilakukan di PT PLN (Persero) Area Makassar Selatan Rayon Mattoangin.

Suatu hasil kegiatan yang baik tentu sangat dipengaruh oleh proses yang baik pendektan pada proses sangat diperlukan agar tujuan perusahaan tercapai secara maksimal yang juga akan berdampak kepada kepuasan konsumen berdasarkan 
hasil perolehan nilai yang di ambil dari penyekoran kuiseioner menunjukan upaya yang telah dilakukan PT. PLN (Persero) Area Makassar Selatan Rayon Mattoangin antara lain pada kegiatan kunci perusahan menetapkan tanggung jawab yang jelas serta mengevaluasi dan mengukur kegiatan kunci, perusahaan juga memastikan interaksi antar satu bagian dengan bagian lain dalam perusahaan berjalan dengan baik melalui pengawasan lansung oleh pimpinan adapun upaya lain yang dilakukan adalah perusahaan mengevaluasi resiko dari kegiatan pelanggan, pemasok dan pihak berkepentingan lainnya.

Dari semua upaya yang digambarkan diatas yang telah dilakukan oelh PT. PLN (Persero) Area Makassar Selatan Rayon Mattoangin menunjukkan penerapan prinsip ISO 9001:2008 yaitu pendekatan proses dikategorikan sangat tinggi terlihat dari upaya dan hasil perolehan nilai yang diperoleh.

\section{Pendekatan Pada Sistem}

Manajemen, Dapat disimpukan dalam indikator Pendekatan pada
Sistem Manajemen mendapatkan perolehan nilai sebesar 83,5 dapat di katakanata sang tinggi terlihat dari hasil analisis sejumlah data pertanyaan yang dilakukan di PT PLN (Persero) Area Makassar Selatan Rayon Mattoangin.

Sebuah perusahaan harus memiliki manajemen yang baik untuk mencapai tujuan organsasi dengan cara mengatur segala bentuk pengelolana dalam perusahaan secara efektif dan efesien agar kedepannya pencapaiannya lebih baik lagi berdasarkan perhitungan nila diatas menunjukkan indikator pendekatan pada sistem manajemen memiliki perolehan sangat tinggi yang berarti PT. PLN (Persero) Area Makassar Selatan Rayon Mattoangin, telah menerapkan beberapa upaya antara lain.

Perusahaan menstrukturkan sistem menuju pencapaian sasaran yang lebih efektif, perusahaan mengupayakan memaksimalkan proses manajemen yang ada dalam perusahaan seperti pelayanan keluhan/pengaduan pelanggan serta perusaaan memberikan pemahaman 
akan tanggung jawab seluruh karyawan dalam perusahaan.

Perolehan hasil scor yang sangat tinggi yang di peroleh dari kuisioner dari semua karyawan menunjukkan PT. PLN (Persero) Area Makassar Selatan Rayon Mattoangin, telah menerapkan indikator tersebut dengan sangat baik.

Sebuah perusahaan harus memiliki manajemen yang baik untuk mencapai tujuan organsasi dengan cara mengatur segala bentuk pengelolana dalam perusahaan secara efektif dan efesien agar kedepannya pencapaiannya lebih baik lagi berdasarkan perhitungan nila diatas menunjukkan indikator pendekatan pada sistem manajemen memiliki perolehan sangat tinggi yang berarti PT. PLN (Persero) Area Makassar Selatan Rayon Mattoangin, telah menerapkan beberapa upaya antara lain,

Perusahaan menstrukturkan sistem menuju pencapaian sasaran yang lebih efektif, perusahaan mengupayakan memaksimalkan proses manajemen yang ada dalam perusahaan seperti pelayanan keluhan/pengaduan pelanggan serta perusaaan memberikan pemahaman akan tanggung jawab seluruh karyawan dalam perusahaan.

Perolehan hasil scor yang sangat tinggi yang di peroleh dari kuisioner dari semua karyawan menunjukkan PT. PLN (Persero) Area Makassar Selatan Rayon Mattoangin, telah menerapkan indikator tersebut dengan sangat baik.

Perbaikan yang Terus Menerus,Dapat disimpukan dalam indikator Perbaikan yang Terus Menerus mendapatkan perolehan nilai sebesar 83,73 dapat di katakan sangat tinggi terlihat dari hasil analisis sejumlah data pertanyaan yang dilakukan di PT PLN (Persero) Area Makassar Selatan Rayon Mattoangin.

Terciptanya Perusahaan yang sesuai dengan visi dan misinya tentu tidak luput dari pengupayaan perbaikan yang terus menerus diperhatikan.Berdasarkan

perhitungan skor perolehan indikator Perbaikan terus menerus dikategorikan sangat tinggi, dikarenakan PT. PLN (Persero) Area 
Makassar Selatan Rayon Mattoangin mengupayakan penetapkan target perbaikan berkelanjutan pada standar tententu serta perusahaan mengidentifikasi perbaikan berkelanjutan atas peralatan dan metode-metode yang efektif.Upaya tersebut telah dilakukan PT. PLN (Persero) Area Makassar Selatan Rayon Mattoangin, dalam pancapaian indikator Perbaikan terus menerus.

Pendekatan Faktual pada Pengambilan Keputusan,Dapat disimpukan dalam indikator Pendekatan Faktual pada Pengambilan Keputusan mendapatkan perolehan nilai sebesar 85,22 dapat di katakan sangat tinggi terlihat dari hasil analisis sejumlah data pertanyaan yang dilakukan di PT PLN (Persero) Area Makassar Selatan Rayon Mattoangin.

Terciptanya Perusahaan yang sesuai dengan visi dan misinya tentu tidak luput dari pengupayaan perbaikan yang terus menerus diperhatikan.

Berdasarkan perhitungan skor perolehan indikator Perbaikan terus menerus dikategorikan sangat tinggi, dikarenakan PT. PLN (Persero) Area
Makassar Selatan Rayon Mattoangin mengupayakan penetapkan target perbaikan berkelanjutan padaa standar tententu serta perusahaan menidentifikasi perbaikan berkelanjutan atas peralatan dan metode-metode yang efektif.Upaya tersebut telah dilakukan PT. PLN (Persero) Area Makassar Selatan Rayon Mattoangin, dalam pancapaian indikator Perbaikan terus menerus.

Hubungan yang Saling Menguntungkan Dengan Pemasok, Dapat disimpukan dalam indikator. mendapatkan perolehan nilai sebesar 84,28 dapat di katakana sangat tinggi terlihat dari hasil analisis sejumlah data pertanyaan yang dilakukan di PT PLN (Persero) Area Makassar Selatan Rayon Mattoangin.

Perusahaan dan supplier pada dasarnya adalah saling ketergantungan juga harus saling menguntungkan dan harus terus meningkatkan kemampuan keduanya untuk mencapai tujuan yang sesuai dengan visi dan misi masing-masing organisasi.

Mutu produk yang diberikan oleh pihak supplier sangat 
mempengaruh hasil akhir mutu produk (barang/jasa), dari hal hal tersebut tentunya perusahaan harus mengcontrol kinerja supplier adapun upaya yang telah dilakukan terkait prinsip ini adalah perusahaan mengidentifikasi hubungan yang menyeimbangkan keuntungan jangka pendek dengan pertimbangkan jangka panjang, selain itu PT. PLN (Persero) Area Makassar Selatan Rayon Mattoangin selalu berupaya membina hubungna yang baik dengan cara memperlakukan supplier sebagai mitra kerja serta perusahaan selalu memastikan output dari supplier sesuai dengan yang diinginkan guna memastikan hasil akhir barang/jasa yang sesuai dengan yang diinginkan.
Dari upaya upaya yang telah dilakukan PT. PLN (Persero) Area Makassar Selatan Rayon Mattoangin diatas menunjukkan idikator Hubungan yang saling menguntungkan dengan pemasok memalui upaya dan hasil perolehan skor kusioner dapat dikatakan sangat tinggi.

$$
\text { Berdasarkan }
$$

hasil penjumlahan secara keseluruhan indikator dapat disimpulkan bahwa penerapan Sistem Manajemen Mutu ISO 9001:2008 di PT PLN (Persero) Area Makassar Selatan Rayon Mattoangin didapatkan nilai rata-rata 83,60 . hasil dari rata-rata tersebut yaitu :

Tabel 2 Scoring

\begin{tabular}{|c|c|c|}
\hline Scoring & Presentase (\%) & Keterangan \\
\hline $0-20$ & - & Sangat Rendah \\
\hline $21-40$ & - & Rendah \\
\hline $41-60$ & - & Sedang \\
\hline $61-80$ & - & Tinggi \\
\hline $81-100$ & $83.60 \%$ & Sangat Tinggi \\
\hline
\end{tabular}

Sumber Data Primer diolah (2016)

Berdasarkan tabel diatas, penerapan Sistem Manajemen Mutu maka dapat disimpulkan bahwa ISO 9001:2008 di PT PLN (Persero) 
Area Makassar Selatan Rayon Mattoangin diantara 81-100 atau setara dengan $83.60 \%$ yang berarti penerapannya dapat dikatakan sangat tinggi.

\section{Kesimpulan}

Berdasarkan hasil penelitian yang dilakukan mengenai PrinsipPrinsip Sistem Manajemen Mutu ISO 9001:2008 dalam Pelayana Publik PT PLN (Persero) Area Makassar Selatan Rayon Mattoangin maka dapat disimpulkan sebagai berikut:

\section{Prinsip-Prinsip}

Sistem

Manajemen Mutu ISO 9001:2008 dalam Pelayana Publik PT PLN (Persero) Area Makassar Selatan Rayon Mattoangin secara umum di katakana sangat tinggi namun masih terdapat satu indikator yang dengan kategori tinggi yakni indikator kepemimpinan dengan nilai $80,66 \%$ responden Indikator-indikator yang termasuk kategori sangat tinggi dalam variabel adalah indikator Fokus pada pelanggan dengan nilai $84,76 \%$ responden, keterlibatan karyawan dengan nilai 83,58 responden pendekatan proses dengan nilai 83,11 pendekatan pada sistem manajemen dengan nilai $83,5 \%$ perbaikan terus menerus dengan nilai 83,73 pendekatan faktual pada pengambilan keputusan dengan dengan nilai $85,22 \%$ hubungan yang saling mnguntungkan dengan pemasok $84,28 \%$

\section{DAFTAR PUSTAKA}

Badudu, J. S, Sutan Mohammad Zain.2001.Kamus Umum Bahasa Indonesia.Jakarta : Pustaka Sinar Harapan.

Fandy Tjiptono dan Anastasia Diana. 2003. Total Quality Management. Yogyakarta : Edisi Revisi.

Gasperz, Vincent. 2001. Manajemen Kualitas Dalam Industri Jasa, Jakarta: PT. Gramedia Pustaka Utama.

Kasmir. 2003. Bank Dan Lembaga Keuangan lainnya.Jakarta:PT Raja Grafindo Persada

Moenir H.A.S. 2002.Manajemen Pelayanan Umum di Indonesia. Jakarta : Bumi Aksara.

Pasolong, Harbani.2007.Teori Administrasi Publik. Bandung : Alfabeta

Ratminto dan Atik Septiwinarsi. 2005. Manajemen Pelayanan. Yogyakarta: Pustaka Pelajar.

Rivai, Veithzal. 2005.Kepemimpinan Dan Perilaku Organisasi, Jakarta: PT. Raja Grafindo Persada.

Sinambela, Lijan Potlak. 2007. Reformasi Pelayanan Publik: Teori Kebijakan dan 
Implementasi. Jakarta :Bumi

Aksara.

Trigono. 1997. Budaya Kerja

Menciptakan

Iklim yang Kondusif untuk

Meningkatkan Produktivitas Kerja.

Jakarta : PT. Golden Terayon

Press. 